\title{
THE UNIVERSITY COLLEGE OF RHODESIA AND NYASALAND
}

\section{EDUCATING THE NEXT GENERATION}

by

CYRIL A. ROGERS

$$
\text { of the }
$$

University College of Rhodesia and Nyasaland Department of Education

$$
\text { 4. } 2
$$


CYRIL A. . ROGERS

1959

UNIVERSITY COLLEGE OF RHODESIA AND NYASALAND

(1) An address given at Lusaka on the '19th of April, 1959,; to the United Northern Rhodesia Association, Study Conference, No. 3. 
HUMANITY HAS STRUCK ITS TENTS IND IS ON THE MARCH - General J.C.Smuts

\section{HISTORICAL BACKGROUND}

This comment by General Smuts, with its peculiarly South African flavour, is more true of Africa today than when he made it, and it is particularly true of education. The seeds of social change have been planted in this vast continent and the speed of their development is gathering momentum. Black men as well as white are demanding the right to think freely and act independently; they are throwing away the shackles of unquestioning obedience to custom, and excessive awe of tribal authority. Such are the fruits of western ideas and education. It is our task in this discussion to trace the educational forces of Central Africa back to their bases in Britain, to examine the field as it stands, and to sketch some lines of advance for the future.

It is a not uncommon notion that universal primary education, while not yet applied anywhere in Africa, is one of the historic corner-stones of Western society. This of course is not so. Up until very recently, the history of education in England has been very much the history of the voluntary agencies who have attempted, mostly against great odds, to bring the fundamentals of religion and the three $r^{i}$ s to the underpriviledged. State support for universal education comes very recently in the history of Britain. In a number of ways, the phases in educational development in Britain, parallel the phases of development in Central ^frica,although here the time span is greatly shortened. To help us appreciate what the next lines of advance might be in Central Africa, it is necessary to sketch the progress from phase to phase in England.

Phase 1 covers a span of centuries and ends in 1833. Prior to this date, primary education was largely the prerogative of voluntary agencies, and various fee-paying institutions. The iDame Schools ${ }^{p 1}$ of the eighteenth century gave a sort of elementary education, and so did other private institutions, although only too frequently these were staffed by teachers who were quite unfitted for their jobs. The "Charity Schools" established as a rule under the auspices of the 'Society for Promoting Christian Knowledge' (S.P.C.K.) were of help, as were the Sunday schools established toward the end of the eighteenth century. The Sunday school movement developed rapidly and forged a further link in the close relation that has traditionally existed between Ghristianity and education:

1) An address given at Lusaka on the 19th of $A$ pril, 1959, to the United Northern Rhodesiá Association, Study Conference, No. 3. 
pus+ulvid lepresentation and the vote. The first Reform Bill of

1832 quickened the shift of political power toward the common man, and as the shift proceeded, it was more generally realised that education was essential for all. Even so, it was not until 1928 that the 'Equal Franchise Act' gave women the right to be registered as parliamentary electors; in this respect Britain lagged far behind her oversea Dominions.

If we ignore the traditional modes of fifrican education, then Phase 1 in this part of the continent commences with the arrival of the first modern missionaries in 1859, under the leadership of Robert Moffat. This group, members of the London Missionary Society, were given a mission site at Inyati by Mzilikazi, the zulu soldier and settler, and in spite of later opposition from Mzilikazi and his successor, Lobengula, the school flourished. Roman Catholic missionaries arrived at Bulawayo in 1879 and commenced their educational work shortly afterwards, and in 1891, just a year after the pioneer column had forged through to Salisbury, the Dutch Reformed Church made its first contributions to education in Rhodesia. By the end of the century, ten different religious bodies were doing mission and educational work in the country (see Kerr Commission, 1951). These dedicated men felt that if the African were to be brought to accept the word of God, he should be able to read the Bibla. But Christian philosophy extended far beyond this ; it also meant the introduction of medicine, better standards of nutrition, the trades, and eventually, a completely new way of life. The material resources of the early mission schools were not great, distances were fantastic; diseases erippling and opposition sométimes violent. Yet, to their honour, they persevered.

Phase 2 in England ran from 1833 until the first eduration Act of 1870 . During this period the voluntary bodies, mainly of a religious character, developed a system of elementary education with the aid of fees, subscriptions and state grants, the latter, a. time went on, extending beyond mere building grants. Education, although fairly widespread, was not compulsory, and standards varied enormously. Phase 2 in Southern Rhodesia can be ald to date from 1899 when the first Education Ordinance was passed. Although it was concerned mainly with European education, African education was given a little help. It provided that, under certain specified conditions, an allowance of ten shillings per year per pupil could be made to assist the Missions that were providing schooling and industrial training for Africans. The first grants under the Ordiance were made in 1901 when three schools were allocated monies totalling about $£ 133$. This Ordinance reflected the increasing need of the settler community for skilled workers on the land and in industry. But education once started creates new needs ; as European technology advanced so did the need for further African education, and these growing demands obliged the state to increase its share of awistance. Ind there is little doubt that as African education accelerated, so did '-js political awareness and ras demand for a share in Government. It happened like this in England.

Phase 3 of English educ'ation can be said to date from 1870 when the locally elected School Boards were required to provide elementary schools in those areas where the efforts of the voluntary agencies were shown to be insufficient to meet the growing demand for popular education. The $\mathrm{f}_{\mathrm{i}} \mathrm{t}$ of 1870 did not provide schooling overnight for the under-priviledged, far from it, but it did start England on the road to universal, compulsory education.

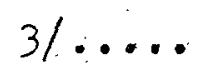


villulen autend school for at least eight years, as against $80 \%$

of African children commencing schooling in Southern Rhodesia.

Of the African children who begin, for a variety of reasons, only about $4 \%$ complete eight years of schooling, while in Northern Rhodesia and Nyasaland, the percentage who begin is only half of that for Southern Rhodesia. Nevertheless, the groundwork has been laid, and well laid in Southern Rhodesia, for the serious contemplation of a surge through to phase.3 in the african system.

\section{THE EDUCATION SYSTEN AND POSBIBLE LINES} OF MODIFIC ITION

Although the tasks of educational provision differcin the three territories, there is one feature which they demonstrate in common. With the arrival of European settlers in Southern Rhodesia and other parts, a second system of education grew up, separate from the African system. The first schools for Europeans were often established by the churches too, but because of differentes in language, sotial background, race and (it seems) numbers, little thought was given to educating Africans and Europeans together. Thus, when in 1953 Federation between the three territories was effected, it was decided to keep the African and non-African systems separate, with the Federal government assuming responsibility for European, 1 sian and Coloured children, and the territorial government assuming responsibility for nfrican education. The administrative division: of African and non-African education was not new. From the time of the first Education Ordinance, African schools had been administered from an Education Department that was also concerned with European schools. But in 1924, a year after Southern Rhodesia abtained responsible government, a Commission was appointed to enquire into hrican education. It recommended that, because of the special problems of learning and teaching involved, African education should be controlled by a separate Department. This was effected in 1927 when Mr. H. Jowitt was appointed as the first Director of Native Education in Douthern Rhodesia. $A^{S}$ I intend to show in a little while, it is my belief that African and European children should now be brought together again.

There are many ways that the administration of education can be approached, but for the sake of convenience let us look at two that are fairly distinct.

Type 1. The first is for the State to assist the educative agencies that arise spontaneously, to encourage certain standards, to require communities of lesser size than the state to provide education for all. It may finance the whole of education from its central funds, or part of it, but ultimately the government's finction is one of advice and stimulation, not of direct control.

Type 2. The second way is for the Government to control all schools, to provide all or nearly all the monies required for education, and to direct their disbursement. The first method has evolved in and is fairly typical of England; the second is becoming not uncommon among some of the newer states that have emerged since the war, and it is usual in the authoritarian states. Because I believe that administration something like the first type is more desirable, it is necessary to see how it evolved.

As I have stated, the early history of education in England, is a record of the contributions of voluntary bodies, the churches, the guilds, the hospitals and so on. When the state was prodded into 
efficient education authorities, while at the same time fostering and developing the richness of voluntary interest and contributions. Each county has a Local Education futhority which is responsible for education wïthin its area, including the raising of monies to help finance it. because of the demand for facilities beyond the financial capacity of most countiss, the Ministry of Education now meets the largest portion of the overall bill. It is important to note, however, that the Ministry of Education, while he does possess considerable authority if he chose to use it, still regards it as his chief function to advise on and promote educational development, rather than control it. And the same can be said of the various Consultative Committees that are set up and which report on education.

Now it is my firm belief that a decentralised system of education, as free as is possible from state control, serves best the community which wishes to implant and nourish the traditional inglo-Saxon freedoms. It may be argued that these have little to do with ffrica, where millions of people are still too backward, too uneducated to know anything of a free society as we know it from our British heritage. The reply is that we must kaep our democratic goals firmly in mind, if we believe in them, or else we may become confused about them, or forget them:

Now the concept of freedom, which seems basic to English speaking and other communities, has been in danger of extinction even as it has evolved. On the one hand the law has guarded the rights of the individual, and on the other, the inexorable growth of the machinery of government has rendered the individual less important; it has made more difficult the exercise of his rights and the performance of his duties. $N$ lso, it is a sorry fact that in some of the countries that I have seen in Africa, the schools are being used for government propaganda rather than for growth towards any democratic ideal. For these reasons, and others could be advanced, I believe that the first type of educational administration that has been described, is to be preferred.

But in the Federation, however, we have many special problems, one of them being that we possess rather too much variety without an underlying feeling of nationhood: All societies, if they are to survive from internal disorder and external threat, must have a fundamental degree of social cohesion. This has been true of former times as well as of today, and it applies to the primitive tribal groups of fustralia as well as the highly developed states of the 20th century. Within a framework of social cohesion it was possible in 19th century England and America to preserve a large measure of local autonomy and different folkways.

Through the great voluntary agencias of the Federation, we have the very necessary diversity that I have been speaking about; our next step is to forge national unity. In one state (at least) in Africa that I visited recently, this was being done by authoritarian means; I feel that we can achieve a much more permanent and desirable result from democratic procedures. Our aim ought to be to Federalise both the ffrican and non-African education systems. However, there is some danger in this. Nowhere is the relation between the government and the governed likely to be more delicate than in the field of education. It is much too facile 
aanger is present. It has happened in Germany, Italy, Russia, and China, and it is now happening within the British Commonwealth. It has not happened before within the Commonwealth because we have gbeen living off the hump of an intellectual heritage drawn from the mother country. But as the links became mure tenuous through the passage of time, it is imperative that we take stock and start ploughing something back into our heritage.

Figure 1 gives a tentative and simplified illustration of a system of educational administration that we might consider. It is not intended to be definitive, but some general principles can be observed.

\section{An Education Commission}

It is my contention that we should consider seriously the establishment of some body, which might be called an Education Commission, which would act as a buffer between the whole education system - African and European - and the state. This body, as I see it, should be something like the University Grants Committee as it works in Britain. It should be an independent judicialy body, enjoying the confidence of the Federal state, and with direct access to the treasury. On this Commission the Federal Government would be represented, but in keeping with the principle of decentralisation, the territorial Governments should also be represented, and the Christian bodies. If such a Commission were established, its duties could be defined in terms such as the following: ir to promote the education of all the peoples of the Federation of Rhodesia and Nyasaland, and the progressive development of institutions devoted to that purpose, and to secure the effective execution by the Territorial Education Boards, of the Commissions policy for providing a varied and comprehensive educational service in every area". The national policy of the Federation would be established by the Commission, so that it would embrace both the ifrican and non-nfrican systems. nt the moment there is one policy for the Furopean schools and three territorial policies for the African. If we wish to build a modern state, with a sense of internal unity and a common pride of citizenship, then one national philosophy of education, with a policy stemming from it, is needed. Mnother function of the Education Commission; as I see it, would be the equalisation of educational opportunity through the differential allocation of Federal monies to the Territorial Education Boards. (To be discussed).

Just as a first talking point, the composition of the Education Commission should include the following persons:-

The Minister or Secretary of Education. (Chair)

The Chairman of the N.R. Education Board.

The Secretary of the N.R. " $\%$ A member of the N.R.

The Chairman of the Nyasaland Education Board. The Secretary of the Nyasaland
$A$ member of the Nyasaland.

The Chairman of the S.R. Education Board

The Secretary of the S.R. $\because "$ ".

A member of the S.R.

Six members elected by the Religious Organisations. 
whicn secures education for all. A subsidiary effect of this proposal, but an important one, would be to remove the teaching profession from the Civil Service.

Territorial Education Boards. Although the intention of the scheme is to have national educational policy formulated by a Commission at the Federal level, it is still necessary to have it implemented by the Territorial Grvernments. To secure this, it would be the responsibility of each territorial government to work through an Tiduation Board, some of whose members would be professional and. others elected. Among the elected members should be included representatives of the Religious and voluntary bodies, and African and non-African iocal bodies. These recommendations flow from my thesis that once national policy is formulated, full reign should be given to the wealth of variety - both local and religious - that abounds in the Federation. The more that the ordinary citizen can be involved in thinking about, and executing, a philosophy of education, the more likaly is that philosophy to succeed. After all, the sum of the thoughts of all of us, is the collective wisdom of the community.

Now it is to be expected that there may be some overlap between the Federal and Territorial governments on matters of education, and that some of the Acts may be in conflict. But their constitutionality could always be tested in the SupremenCourt, a usual method adopted by people adhering to Anglo-Saxon concepts of justice.

Any such plans for reorganising the education system, would have to be considered with great care. If my comments in any way stimulate a reappraisal of the present structure, then some purpose will be served.

The comments which follow refer to educational growth that could stem from the present or a restructured system.

Private Schoolsthat receive State Aid. So far in this thesis, Ihave constantly advocated an Education system which places a premium on variety and freedom. Consequently, one must not eschew the topic which worries some, of State aid to Church and endowed schools. In a society that hopes to be democratic, every person has a claim, as a citizen, to a full and, liberal education. And the first gimmerings of this concept come to us from the churches rather than the state. Traditionally, in Central $\Lambda$ frica as well as in England, the Churches and voluntery bodies were first in the field, and our concern for the future should. not only be to preserve thair position, but to advance it. For this reason it is suggested that they should have direct access to the Territorial Education Boards through elected representatives.

The different governments of the Federation have always recognized the vast contributions of the Missions to education, and have supported them well. For example, in Southern Rhodesia in 1958 there were 2,578 lower Primary schools and only 32 of these were administered by the Government. Hust of them were aided Mission Schools. Over the years, the amounts spent on African education by the government have risen steadily as Table I shows. 


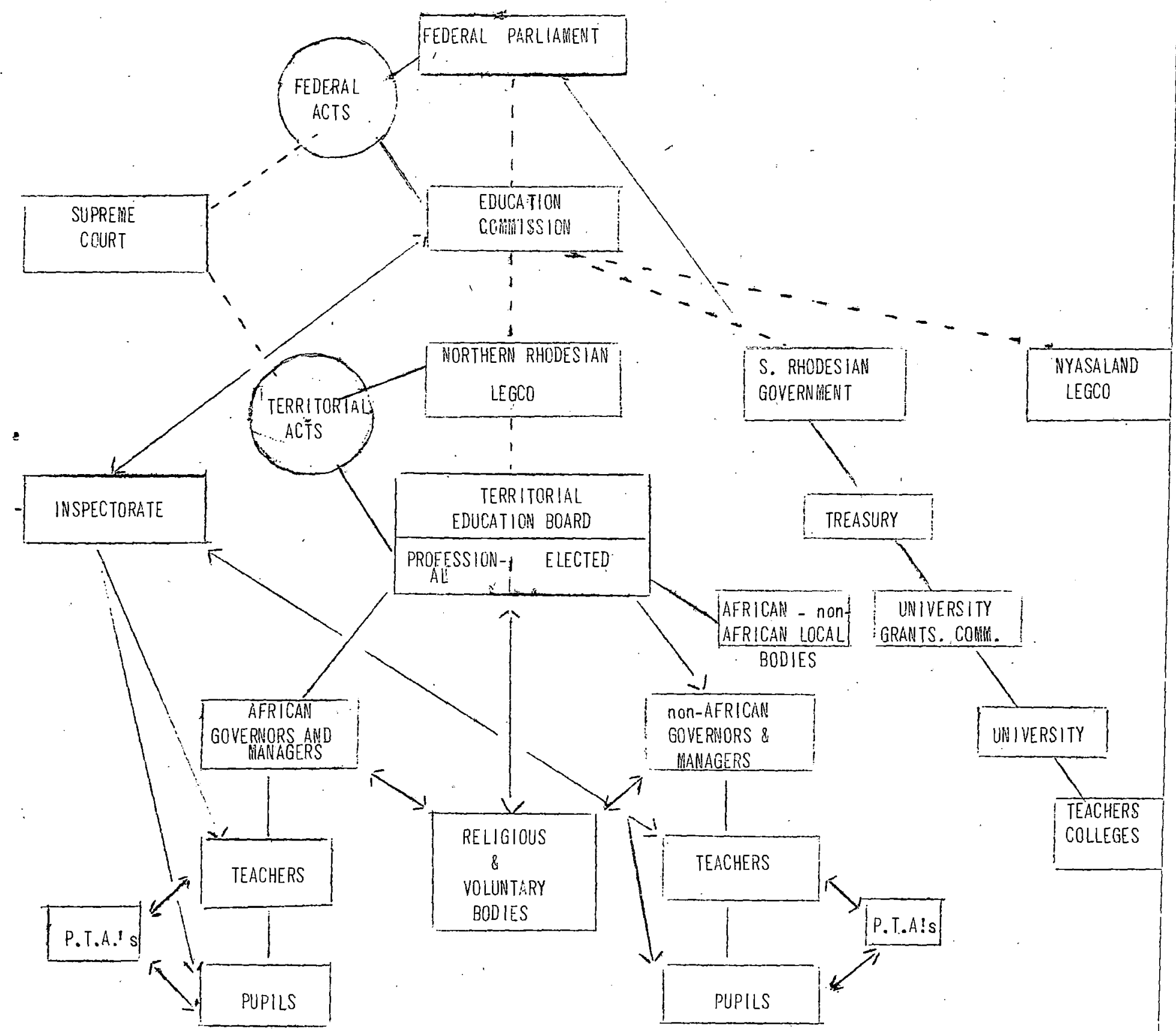

FIGURE 1. A tentative and simplified diagram to illustrate a system of educational administration for the Federation of Rhodesia and Nyasaland 


\begin{tabular}{lrrrrr} 
N.R. & $£ 600,000$ & $5.0 \%$ & N.R. & $£ 2,000,000$ & $10 \%$ \\
S.R. & 500,000 & $3.2 \%$ & S.R. & $1,700,000$ & $8 \%$ \\
Ny. & 200,000 & $6.6 \%$ & Ny. & 800,000 & $16 \%$ \\
Total & $1,300,000$ & $5.0 \%$ & Total & $4,500,000$ & $10 \%$ \\
\hline
\end{tabular}

In spite of serious fluctuations in the economy of the Federation, there is a steady increase in expenditure on African education. In Nyasaland, where a five year plan has been costed, it is proposed to increase the children enrolled from the 1956 figure of $41 \%$ to $57 \%$ by the end of 1961 . This will involve, among other things, building 2 le new primary schools, training about 1,200 new teachers and bumping expenditure from $£ 800,000$ to $£ 1,100,000$, an increase of nearly $40 \%$ over the period of 1957-1961.

But the contributions of the churches, in terms of buildings, devoted teaching and equipment, are beyond calculation. Without them, the state education system would not be handicapped, it would be crippled. Thus on the grounds of economics alone, the voluntary bodies should not be allowed to languish. But there are other reasons, more cogent than financial, why the mission schools are important. They demonstrate variety, cross-fertilisation and, so important in Africa, resistance toward any possible encroachment of the state. The lessons on this point are too obvious to need labouring. However, where the State grants the Mission schools the financial support and the freedom which they enjoy in the Federation, this places an equal responsibility on the Missions to see that their monies are spent wisely, and to demonstrate how they are being spent. Is I see the situation at the moment, the Governments have no desire to take over the Mission schools; the one thing that would turn thinking along such lines would be if the Missions themselves faltered in the sterling work they are doing.

It is true that educational standards vary in the mission schools from very good to very inadequate, the latter generally a condition of inadequate resources and the expanding needs of education. It is possibly for this reason that many Africans with whom I have discussed the matter, believe that the panacea for educational inadequacies is for the state to take over the church schools, and pump the resources of the state into them. This view I find alarmingly common not only among Africans, but Europeans too, who have not learned the lessons of history. The theme in my argument is that the resources of the state should be used to support the voluntary bodies, and to provide education (primary, secondary, trade, technical and adult) where the efforts of these bodies are insufficient to meet the demands made on them.

Teacher Training. Another aspect of education that can be considered from the viewpoint of decentralisation is that of teacher training. At the outset it is important to draw a distinction between the education and the training of teachers. It is as important for the teacher to be well educated as it is for the doctor, or the lawyer, or the politician. In another way, he who would educate othars, must himself be educated. It seems basic that any scheme 
Given that teachers should be reasonably cultured and educated persons, what is the most effective means of ensuring that their training is in keping with the principles of independence from the state? One of the clearest statements on this matter emanates from the McNair Report of 1944. The education and the training of teachers should be a function of the University. This means

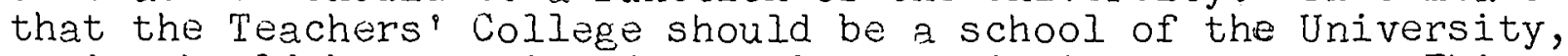
or it should be associated closely with it in some way. This course cannot be advocated too strongly. The University, traditionally, is the repository of freedom in the democratic community. It has a time-honoured independence and freedom to search for truth, free of governmental regulation, and official edict.

Furthermore, as the McNair Report emphasised, the University has a distinct connection with, and obligation to, the education systam as a whold. Its vitality depends, in no small measure, upon the kind of education given in the schools, both primary and secondary, and the schools in turn look to the Universities for some measure of leadership in matters that are, in the end, matters of philosophy.

As Professor Fletcher (1958b) has pointed out elsewhere, the Governments of the Federation, acting through the inter-Governmental Liason Committee on Education ' have agreed already to the Association of Teachers' Colleges with the University. Ultimately, it is hoped that all Teacher Training Colleges will be associated with the University Institute of Education, and the certificates awardad to teachers will be certificates of the University College. This step taken by the Governments is a most significant and farreaching one, and demonstrates their faith in the role that an independent teaching profession can play in the development of a democratic community.

\section{DIFFERENT DEGRESS OF OPPORTUNITY FOR DIFFERENT R/LES}

'The Europeans who settled in Central Africa brought with them a way of life that was very different from the African, and following the traditions that they knew elsewhere, they demanded education for all their children, and opportunities for academic and economic advancement. There is little doubt that the quality of European education, and the rewards which it brings, have influenced substantially the African demand for more and better schools. Even though contacts between the European and African systems are not as great as they could be, it is nevertheless trua that the European schools and tho system of teachur training, furnish very good models for Africans to emulate.

is we have noted, the non-nfrican system of education in Central ifrica is laid on a foundation of universal primary education, phase 3 of the historical sequence which I outlined at the beginning. The fifrican Education system has reached phase 2, and the foundation has been well laid for the next surge through to educational parity. In terms of teachers, buildings, equipment, land and other matters, the implementation of phase 3. will be very costly indeed, and certainly cannot be achieved-overnight. Between 1947 and 1957, the population of the Federation rose by $27 \%$ and the number of 1 fricans beginning school - approximately 200,000 in 1957 - 
ullizion, but the annual African increase was $14.5 \%$ as against $11 \%$ for Europeans. From other figures it can be shown that while the rise in national income for hfricans and auropeans combined is around $12 \%$ per annum, the increase in expenditure on African education is 25\%. As Professor Fletcher (1958a) points out, "This is as it should be, for education is a form of investment in the future ".

Much of the problem then, boils down to plain economics.. Both the African and European populations are growing at a very fast rate compared with many of the older nations, and to face the cost of education greater productivity must be achieved and further capital must be attracted to do so.. Is the report of the Cambridge Conference on 'African Education' says : "i. .. it would be our hope that each 'phase' of advance towards this goal (100\% of children receiving eight to ten years of compulsory education). would result in an increase of wealth sufficient to support an educational advance in the next phase.: But because there is a time lag between money invested in education and its return in wealth, at every stage, educational advance calls for self-sacrifice and self-denial by Africans and Suropeans alike. This is the price that must be paid for advance (See Morris, 1953).

Now while it is easy to recognise the deficiencies in African education, and to see that there is a jast chasm to be bridged before parity is reached with the European system, progress should also be measured against that achieved in other territories. Space does not permit of more than one or two simple comparisons. Ghana, which seems to be in the news a bit these days, has just over $50 \%$ of the children of school-going age at school, as against $80 \%$ in Southern Rhodesia. The provision of primary education in Southern Rhodesia is more widespread than that available in most of the French territories, the Portuguese territories and other British territories in Africa. It is much more widespread than that available in Ethiopia, the oldest ifrican state still extant today.

But having said this, one must still accept the fact that we face crisis today in education in Central Africa. The State and the Churches have been so successful in convincing the African people of the value of education that the demand for it is now greatly in excess of the supply. This has been noted by the Catholic Bishops of Southern Rhodesia (1958). In a profound statement on the problem they observe "that the situation might easily lead to serious disaffection among considerable numbers of a hitherto peaceful and notably patient peoplen: They urge the government to explore every possibility of making available greater funds for African education, including assistance from the Imperial Government or the United Nations Organisations which exist for such purposes. With these suggestions I most strongly agree:

Complicating the problem is the degree of 'wastage' that is a factor in our African education, as well as education in other countries where education is voluntary. Wastage is the term used in the Morris Report on African Education to denote the loss of children from a school during the course provided by that school. The reasons are many and varied and are dealt with fairly fully in the report, but one factor not without influence at the higher levels, is the amount of secondary education that is available. In. the Federation, at the end of 1957, there ware a total of 50 junior and senior secondary schools, giving courses that were academic in nature rather than technical, but only three of these were 
If, however, resources are limited, it may be necessary to make a choice between the extension of primary education and extension at the secondary level. This was a decision that had to be taken in West Africa too, and the choice was the expansion of secondary facilities. At this level, both Ghana and Nigeria seem better served than we are in the Federation. For example, the Nigeria 'Digest of Statistics $1956^{\prime}$ Iists 300 schools teaching at the secondary school 1 evel and 65 of these are approved for the West African School Certificate. The population of Nigeria is about four times as large as the Federation. A broad path has been forged from the primary system through the secondary, to the University, with the result that the University Colleges of Ghana and Ibadan, have well over one thousand Africans between them taking different courses. We cannot match this performance. In terms of priorities then, my belief is that the secondary system should be expanded first in the Federation, because the economic return from this would be both greater and more immediate.

Education for Women and Girls. Within the African system there is a further imbalance which is common all over Africa : this concerns the education of women and girls. The figures, which I won't burden you with, show that in Southern Rhodesia the best provision is made for the education of girls, in Northern Rhodesia the position is poorer, while it is the least satisfactory in Nyasaland: Even so, the position is changing very rapidly, and the authorities are making more and more places available. I difficulty that one has to face continually is the attitude of so many Africans to the education of their womenfolk. The attitude so common is that the place for women is in the home and by the hearth. This attitude has been common (and possibly. still is) in England too, where it was not until the latter half of the nineteenth century that a beginning was made on the systematic provision of secondary education for girls. The rectification of this imbalance lies particularly with the African people themselves; they should remember that when you educate your womenfolk, you educate a nation.

Technical Education. All of our political leaders have emphasised the importance of industry in the rapidly expanding economy of the Federation, and with the completion of the Kariba hydro-electric scheme the pace of expansion will increase even further. Technical education for Europeans covers a wide range, and in both the Rhodesias there are classes for indu'strial, clerical and professional trainees, many of whom are fulfilling apprenticeship requirements for the building, mechanical and motor trades. In Southern Rhodesia there are 17 mission Secondary Schools for Africans which have a technical bias, and two substantial government schools providing eourses in agriculture and building (Fletcher, 1958a). At Limbe, in Nyasaland, the frtisan Training Centre represents a most encouraging start in the provision of courses in the mechanical and building trades for Africans, and may well provide a model for the extension of these facilities elsewhere. But we have a long way to go to meet the requirements of a modern, industralised state, and it may well be at the level of industry and technology that the greatest test of partnership.will come. The number of clerical and professional jobs in any nation is small in comparison with the number available in primary and secondary industry, and if the Federation is to fulfill its destiny of being a great state in Africa, then surely it will have to tap to the full, the resources of all races. 
....nuvidet work, it was not taken by new immigrants like myself ; it was taken by people who had lived and worked in the country for years. Certainly some objected to the education of Africans; nevertheisess, the decision was taken, and once taken the pace and scope have increased continually. Education is like that : once you have embarked on it there is no turning back. The products of primary schools ceeate the pressures for secondary schools, and these in turn create the pressures for entrance to the University. This is normal and as it should be.

\section{THE PROS AND CONS OF INTEGRATION.}

In this discussion I have been asked to examine the pros and cons of that emotive issue 'the integration of schools' for different races. Now this is an issue that can hardly be decided on psychological grounds, it is a matter of educational policy as are so many of the matters discussed in this paper. In have seen fully integrated schools in other parts of the world that have worked to the mutual advantage of $a l l$ in them, and I have seen others that have not en joyed the confidence of parents. It the basis of. success is the general wish of the parents to make them work, but where opposition seems strong, as in Central $\Lambda$ frica, integrated schools have not been seriously considered.

An argument that is used against integration is that differences in language backgrounds complicate the learning process. . Now there is certainly omething in this argument. Studies the world over show that where children of one language background are obliged to learn in a new and strange language, teachers can expect as a matter of course, two to three years and more of educational backwardness. This 13 true of studies done in Wales (Welsh —English), Quebec (French $\rightarrow$ English), Southern California (Spanish $\rightarrow$ English), New Zealand (Maori__English) and it is cartainly true for the situation in Central Africa. The problem has nothing to do with race as such, it has everything to do with language background and, less directly, with cultural background. Where the cultures are fairly similar, for example Welsh and Englisih, the switch of languages is not narmally attended by so many difficulties.. Where they abe fairly distinct, then educational problems do arise. Let us consider a few cases.

Case 1 - where the alien language group is in the minority. Under these circumstances the majority group acts as a vehicle of change, and the minority group learns the new language more quickly and efficiently than when not integrated. Even so, special teaching methods are required betause the minority group is normally backward in educational achievement, and the teacher has to grapple with the problem of older pupils in a class of younger children. Of if the children are promoted largely on age, then the teacher has to group within the class for special treatment, those children who are doing work at a lower level. The psychological problems that may emerge if the situation is not handled with skill, centre round feelings of inadequacy and inferiority.

However, where the public philosophy is one of integration, as in Brazil and New Zealand, these difficulties represent a price which the community considers welliworth paying.

Case 2 - where the alien language group is in the majority. Teaching difficulties tend to be greater in this case because of the specialist treatment that has to be given to the majority, the educationally 
However, the problem of whether to integrate or not, is seldom settled on educational or psychological grounds; it is determined by social philosophy and attitudes. The school system is possibly the most powerful instrument for forging internal cohesion in a nation. In the United States, the schools have played a dramatic role in uniting people of all languages, colours, and creeds into one nation, and the final step is being taken now through the integration of the schools in the Southern States. This intagration, which on the whole has gone smoothly and successfully, has not been unaccompanied by difficulties. In New Zealand, largely by historical accident rather than any peculiar tolerance on the part of the pakeha (white) people, white and brown have always gone to the same schools.

But in one of my studies done in Douthern Rhodesia, it was found that the majority of Buropian voters were not in favour of integration (Rogers, 1959). Even so, there is no defensible reason why the Churches should not be permitted to experiment with integrated schools, to become more familiar with the magnitude of the task and possible ways of grappling with it. On matters such as this, the state system of education is generally less venturesome than the voluntary agencies, and is less likely to take the initiative.

This brings us back to the problem we opened with, if we accept that the integration of schools is not a practicable issue, at the moment. How do we use the school system of the gducation Commission to start on the road to national unity ? One route is through the English language, the subject of a recent conference Chaired by Professor Parker (1958), a visiting scholar at the University College. At the Conference, the importance of Fnglish was stressed, not only as a means of communication, but because of the wastern technological way of life it broughtwith it. It is a difficult decision to make, and one that will probably be objected to by many Europeans and Africans, but there is much evidence to sugeest that real equality can only come about by the replacement of the African languages by English. A similar hard-headed decision was made in New Zealand to achieve national cohesion, and to help equalise the educational, economic and social opportunities of the Maoris. Their own language has been retained as a second language, and unglish is, for the majority of Maoris, now their vernacular tongue. I am aware that there are other routes to national unity, but I would be prepared to argue for this one in Central Africa.

Before concluding, it should be pointed out that as the language Eap is narrowed, the educational problems associated with integrated schools will fall zway proportionately. The gap at the secondary level is likely to close much soonar than at the primary level, and where this happens, the case against integrated secondary schools would have to be argued on grounds other than educational.

\section{TOWARDS A PHILOSOPHY OF EDUCATION}

Throughout this paper. I have been arguing for a system of education that is consonant with the democratic creed which is implicit in the values to which Anglo-Saxon peoples subscribe. These values, the noblest which men can believe in, are not easy of attainment; but they are goals to which we can aspire.

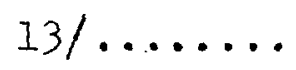


sunter with economic justice, co-operation between peoples, and tolerance of the minority, can hardly be challenged as basic to parliamentary democracy. It is important that we recognise and implement: the democratic creed in Central Africa, even though the task be incredibly difficult and the road long. Only by doing so, do we demonstrate the superiority of our way of life, to the authoritarian rule of Communism, an alien philosophy which competes for the mind and souls of men on this continent and. everywhere.

History shows us that an authoritarian society is easier to implement than democracy; it places power in the hands of the state, rather than in the hands of the individual, where we believe it belongs. But rights imply duties, and in a free country these are so difficult to shoulder. with consistency. Human beings are fragile, and yet they possess some kind of spiritual quality which can bespond to the difficult challenge of democracy, provided they are educated to accept their duties as free men, in a free society. The task before us will be long and arduous, let there be no mistake about that, yet it is infinitely more worthwhile, nore Christian, more uplifiing than anything that can be offered by a , totalitarian society.

In Central Africa, the Churches and the State have recognised the claim that all men have on society for education; an education that will lead men to accept their responsibilities in a democratic society. This claim can be expressed as an aim and there are few more noble interpretations of it than that given by a humble scot, Peter Fraser, who became Prime Minister of New Zealand. "The government's objective, broadly expressed, is that every person, whatever his lavel of academic ability, whether he be rich or poor; whether he live in town or country, has a right, as a citizen, to a free education of the kind for which he is best fittêdsand to the fullest extent of his power."

It will be a long time before we realise this aim in Central Africa, ladies and gentlement but if we do, then democracy will not have failed. 
wonups of Southern Rhodesia (1958), Memorandum on African Education. Statement released after the annual meeting held in Salisbury, Aprill4th .

2) Fletcher, B.A. (1958a) A Short Report on the Background of Educational Development in the Federation. Salisbury ? U.C.R.N. Institute of Education. Pp. II.

3) Fletcher, B.A. (1958b). The Work of an Institute of Education in Central lifrica. Salisbury: U.C.R.N., Institute of Education $\mathrm{Pp} \cdot 35$.

4) Hutchins, R.M. (1949) What Price Freedom? New York Times, July 7 th.

5) Kerr, A. (Chairman)(1951), Report of the Native Education Inquiry Commission. Bulawayo : Government Printer. Pp. 88

6) Morris, Sir Philip (Chairman)(1953), African Education: A Study of Educational Policy and Practice in British Tropical Africa. Oxford University Press . Pp. 187

7) Nigeria (1956), Digest of Statistics. Lagos : Federal Education Department. Pp. 36 .

8) Parker, F. (1958), Report of a Conference on the Teaching of English in African Schools. Salisbury: U.C.R.N. Institute of Education, Pp. 38 .

9) Rogers, C.A., (1958), The Conflict of Philosophies in Africa. The Shield, No. 156, $11-14$.

10) Rogers, C.A. (1959), The Structure of Political Attitudes in Southern Rhodesia. To appear. 


\section{(c) (1) (9)}

This work is licensed under a

Creative Commons

Attribution - NonCommercial - NoDerivs 3.0 License.

To view a copy of the license please see:

http://creativecommons.ora/licenses/bv-nc-nd/3.0/ 